\title{
Bardet-Biedl Syndrome Caused by Skipping of SCLT1 Complicated by Microvesicular Steatohepatitis
}

\author{
Kentaro Horiuchi ${ }^{1}$, Tomomi Kogiso ${ }^{1}$, Takaomi Sagawa ${ }^{1}$, Taito Ito ${ }^{1}$, Makiko Taniai ${ }^{1}$, \\ Kenichiro Miura ${ }^{2}$, Motoshi Hattori ${ }^{2}$, Naoya Morisada ${ }^{3}$, \\ Etsuko Hashimoto ${ }^{4}$ and Katsutoshi Tokushige ${ }^{1}$
}

\begin{abstract}
:
We treated the case of a 22-year-old male patient with liver dysfunction. At 1 year of age, hepatic fibrosis was suspected. In addition, due to the presence of retinitis pigmentosa, renal failure, obesity, mental retardation, and hypogonadism, he was diagnosed with Bardet-Biedl syndrome (BBS). Skipping of exons 14 and 17 in the sodium channel and clathrin linker 1 (SCLT1) gene was observed. At 22 years of age, the liver enzyme levels were further elevated and a diagnosis of microvesicular steatohepatitis was made. Insulin resistance, a reduction of muscle mass, an impairment of the fatty acid metabolism, and hyperleptinemia in this syndrome may cause steatohepatitis.
\end{abstract}

Key words: Bardet-Biedl syndrome, hepatic fibrosis, microvesicular steatohepatitis, sodium channel and clathrin linker 1 (SCLT1), hyperleptinemia

(Intern Med 59: 2719-2724, 2020)

(DOI: 10.2169/internalmedicine.5045-20)

\section{Introduction}

Bardet-Biedl Syndrome (BBS) is a rare human hereditary autosomal recessive disorder that typically manifests with obesity, retinopathy, renal defects, polydactyly, learning disabilities, and hypogenitalism (1-3). The ductal plate malformation is a developmental abnormality of the portobiliary system $(4,5)$. A lack of primary villi results in malformations in the brain, retina, kidney, and limbs; these are known as ciliopathies $(6,7)$. Other ciliopathies cause the liver diseases hepatic fibrosis, Caroli syndrome, and polycystic liver disease. BBS has an estimated prevalence of 1/125,000-1/ 160,000 in Europe $(8,9)$. There have been limited reports in Japan, however, and the first nationwide survey revealed only seven patients with clinically definitive BBS (10). A number of complications of BBS have been reported, including red-cone dystrophy in $93 \%$ of cases, polydactyly in $63-81 \%$, genital anomalies in 59-98\%, renal anomalies in
$53 \%$, and learning difficulties in $61 \%(6)$. Moreover, 72 $92 \%$ of such patients show obesity beginning in early childhood, with the rate increasing with age (11).

In summary, we experienced a case of BBS with hepatic fibrosis and steatohepatitis that exhibited a prolonged elevation of the liver enzymes. This study was conducted in accordance with the principles of the Declaration of Helsinki and the ethical principles of Tokyo Women's Medical University Hospital (Tokyo, Japan).

\section{Case Report}

We experienced the case of a 22-year-old male patient who was admitted to our hospital with liver dysfunction. He had no relevant family history. He was born at 41 weeks of gestation with a body weight of $3,442 \mathrm{~g}$. He had neonatal asphyxia and meconium aspiration syndrome and was treated in the intensive care unit. At 1 year of age, his transaminase levels continued to be elevated, and a liver biopsy

\footnotetext{
${ }^{1}$ Institute of Gastroenterology, Department of Internal Medicine, Tokyo Women's Medical University, Japan, ${ }^{2}$ Department of Pediatric Nephrology, Tokyo Women's Medical University, Japan, ${ }^{3}$ Department of Pediatrics, Kobe University Graduate School of Medicine, Japan and ${ }^{4}$ Seibu Railway Company Health Support Center, Japan

Received for publication April 9, 2020; Accepted for publication May 27, 2020

Correspondence to Dr. Tomomi Kogiso, kogiso.tomomi@twmu.ac.jp
} 
revealed hepatic fibrosis. Retinitis pigmentosa was noted at 2 years of age, and due to obesity, mental retardation, and hypogonadism, he was diagnosed with BBS. At 10 years of age, the patient was referred to our hospital for peritoneal dialysis due to renal dysfunction. At 12 years of age, he underwent living-donor kidney transplantation with his father as the donor. No significant abnormalities were detected on brain computed tomography (CT).

At 19 years of age, he was referred to our department due to liver dysfunction. At that time, his body weight was 57 $\mathrm{kg}$ and his height was $142 \mathrm{~cm}$ [body mass index (BMI) 28.7 $\left.\mathrm{kg} / \mathrm{m}^{2}\right]$. He had elevated liver enzyme levels: aspartate aminotransferase (AST), 30-50 U/L; alanine aminotransferase (ALT), 50-100 U/L; and gamma-glutamyl transferase $(\gamma-\mathrm{GTP}), 100 \mathrm{U} / \mathrm{L}$. The serum levels of prolactin, adrenocor-

Table 1. Levels of Pituitary and Adrenal Hormones at 19 Years of Age.

\begin{tabular}{lcc}
\hline & Range & Value \\
\hline Prolactin & $<15.0$ & $17.2 \mathrm{ng} / \mathrm{mL}$ \\
Adrenocorticotropic hormone & $7.2-63.3$ & $67.4 \mathrm{pg} / \mathrm{mL}$ \\
LH & $1.7-11.2$ & $4.3 \mathrm{mIU} / \mathrm{mL}$ \\
FSH & $2.1-18.6$ & $1.8 \mathrm{mIU} / \mathrm{mL}$ \\
Growth hormone & $<2.47$ & $<0.03 \mathrm{ng} / \mathrm{mL}$ \\
Insulin-like growth factor-1 & $143-501$ & $219 \mathrm{ng} / \mathrm{mL}$ \\
TSH & $0.500-5.00$ & $0.940 \mu \mathrm{IU} / \mathrm{mL}$ \\
Cortisol & $4.0-18.3$ & $19.2 \mu \mathrm{g} / \mathrm{dL}$ \\
Aldosterone & $35.7-240$ & $249 \mathrm{ng} / \mathrm{mL}$ \\
DHEA-S & $24-537$ & $357 \mu \mathrm{g} / \mathrm{dL}$ \\
11-OHCS & $7.0-23.0$ & $18.7 \mu \mathrm{g} / \mathrm{dL}$ \\
Testosterone & $284-799$ & $401.6 \mathrm{ng} / \mathrm{dL}$ \\
\hline
\end{tabular}

TSH: thyroid-stimulating hormone, DHEA-S: dehydroepiandrosterone sulfate (CLEIA method), 11-OHCS: 11-hydroxycorticosteroid ticotropic hormone, and cortisol were also slightly elevated to $17.2 \mathrm{ng} / \mathrm{mL}, 67.4 \mathrm{pg} / \mathrm{mL}$, and $19.2 \mu \mathrm{g} / \mathrm{dL}$, respectively (Table 1). The patient's testosterone level was $401.6 \mathrm{ng} / \mathrm{dL}$ and that of aldosterone was $249 \mathrm{pg} / \mathrm{mL}$. The levels of other androgens and gonadotropins were within the normal range. His growth hormone level was low $(<0.03 \mathrm{ng} / \mathrm{mL})$, but that of insulin-like growth factor-1 $(219 \mathrm{ng} / \mathrm{mL})$ was within the normal range. He was started on a fat- and sugar-restricted diet $(1,000 \mathrm{kcal} / \mathrm{day})$. However, his transaminase levels increased further: AST, $155 \mathrm{U} / \mathrm{L}$; ALT, $422 \mathrm{U} / \mathrm{L}$; and $\gamma$-GTP, $235 \mathrm{U} / \mathrm{L}$. His diet was changed to $1,400 \mathrm{kcal} /$ day, after which his transaminase levels improved: AST, $41 \mathrm{U} / \mathrm{L}$; ALT, $119 \mathrm{U} / \mathrm{L}$; and $\gamma$-GTP, $216 \mathrm{U} / \mathrm{L}$. The serum levels of total cholesterol and triglyceride had increased to 696 and 483 $\mathrm{mg} / \mathrm{dL}$, respectively. The administration of ezetimibe was started at 21 years of age. After 3 months of treatment, his transaminase levels had increased: AST, $90 \mathrm{U} / \mathrm{L}$; ALT, 211 U/L; and $\gamma$-GTP, $339 \mathrm{U} / \mathrm{L}$. Due to a suspicion of druginduced liver injury (DILI) caused by ezetimibe, treatment with that drug was stopped. At 22 years of age, bezafibrate was started and his transaminase levels improved after 2 weeks of treatment (Fig. 1). However, the serum level of creatinine increased from 1.71 to $1.96 \mathrm{mg} / \mathrm{dL}$, so bezafibrate was stopped. After 3 months, his serum creatinine level improved and a half dose of bezafibrate was restarted. After 2 weeks of treatment, the transaminase and creatinine levels were again elevated (creatinine, $1.93 \mathrm{mg} / \mathrm{dL}$; AST, $129 \mathrm{U} / \mathrm{L}$; ALT, $230 \mathrm{U} / \mathrm{L}$; and $\gamma$-GTP, $247 \mathrm{U} / \mathrm{L}$ ), which continued after the discontinuation of treatment.

The patient was admitted to our hospital for an evaluation of liver dysfunction. At that time, the patient was $156.5 \mathrm{~cm}$ in height, $84.5 \mathrm{~kg}$ in body weight (BMI $34.5 \mathrm{~kg} / \mathrm{m}^{2}$ ), and $110.8 \mathrm{~cm}$ in waist circumference. The results of biochemical

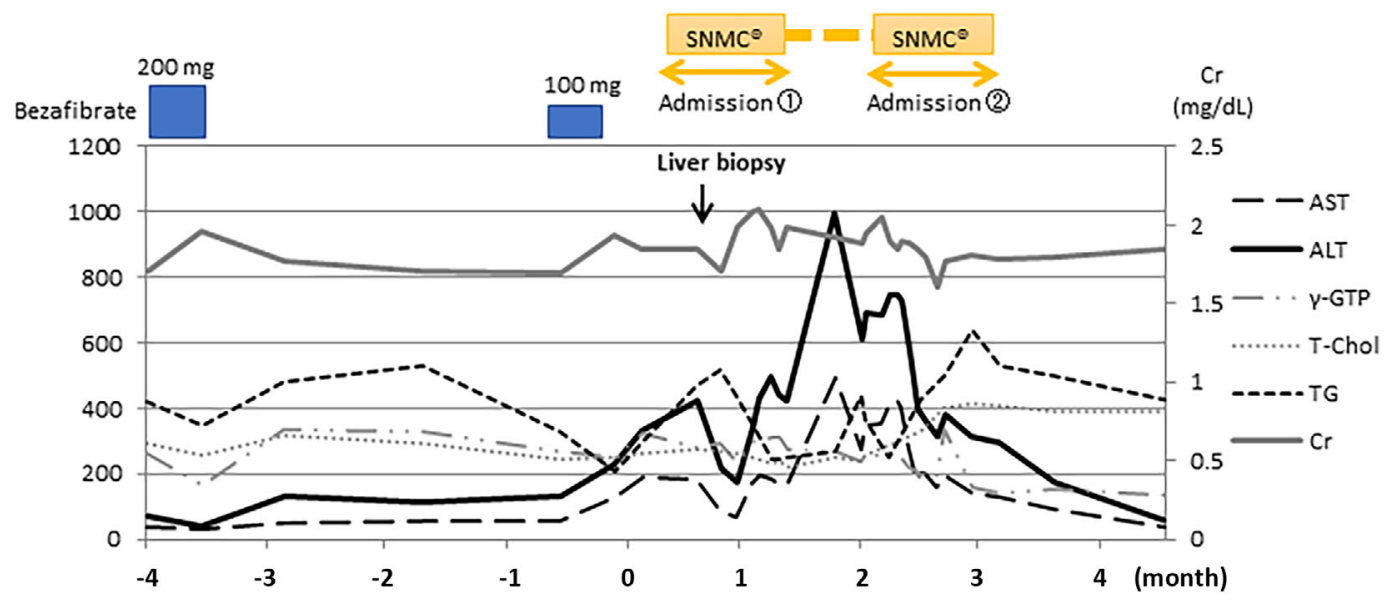

Figure 1. Clinical course. The AST level was increased to 30-50 U/L, ALT to 50-100 U/L, and $\gamma$-GTP to $100 \mathrm{U} / \mathrm{L}$ until 21 years of age (201X-1 year). After the administration of bezafibrate at 22 years of age (201X year), the transaminase levels increased (AST, $86 \mathrm{U} / \mathrm{L}$; ALT, $219 \mathrm{U} / \mathrm{L}$; and $\gamma$-GTP, $399 \mathrm{U} / \mathrm{L}$ ) and the patient was admitted to our hospital. Treatment with ursodeoxycholic acid and Stronger NeoMinophagen ${ }^{\circledR} \mathrm{C}\left(\mathrm{SNMC}^{\circledR}\right)$ was started and the transaminase levels decreased. However, the transaminase levels again became elevated after tapering $\mathrm{SNMC}^{\circledR}$ treatment and the patient required hospitalization on two occasions. 
Table 2. Laboratory Data at the Time of Admission to Our Hospital.

\begin{tabular}{|c|c|c|c|}
\hline Hematology & & Coagulation & \\
\hline WBC & $6,130 / \mu \mathrm{L}$ & PT-INR & 0.90 \\
\hline $\mathrm{RBC}$ & $3.87 \times 10^{6} / \mu \mathrm{L}$ & РT\% & $>100.0 \%$ \\
\hline $\mathrm{Hb}$ & $11.5 \mathrm{~g} / \mathrm{dL}$ & & \\
\hline $\mathrm{Ht}$ & $35.4 \%$ & Hormone & \\
\hline PLT & $29.7 \times 10^{4} / \mu \mathrm{L}$ & Leptin & 197 ng/mL \\
\hline Biochemistry & & Serology & \\
\hline TP & $7.5 \mathrm{~g} / \mathrm{dL}$ & $\operatorname{IgG}$ & $898 \mathrm{mg} / \mathrm{dL}$ \\
\hline ALB & $4.6 \mathrm{~g} / \mathrm{dL}$ & $\operatorname{IgM}$ & $125 \mathrm{mg} / \mathrm{dL}$ \\
\hline T-BIL & $0.8 \mathrm{mg} / \mathrm{dL}$ & ANA & $<40$ \\
\hline D-BIL & $0.2 \mathrm{mg} / \mathrm{dL}$ & AMA & $(-)$ \\
\hline $\mathrm{D} / \mathrm{T}$ ratio & 0.38 & & \\
\hline AST & $86 \mathrm{U} / \mathrm{L}$ & Hepatitis virus & \\
\hline ALT & $219 \mathrm{U} / \mathrm{L}$ & HBs antigen & $(-)<0.02 \mathrm{IU} / \mathrm{mL}$ \\
\hline ALP & $399 \mathrm{U} / \mathrm{L}$ & HCV antibody & (-) $\mathrm{COI}$ \\
\hline$\gamma$-GTP & $290 \mathrm{U} / \mathrm{L}$ & & \\
\hline LDH & $357 \mathrm{U} / \mathrm{L}$ & Drug Monitoring & \\
\hline BUN & $29.0 \mathrm{mg} / \mathrm{dL}$ & Cyclosporine & $145 \mathrm{ng} / \mathrm{mL}$ \\
\hline $\mathrm{Cr}$ & $1.71 \mathrm{mg} / \mathrm{dL}$ & & \\
\hline eGFR & $44.4 \mathrm{~mL} / \mathrm{min} / 1.73 \mathrm{~m}^{2}$ & Functional test & \\
\hline $\mathrm{Na}$ & $139 \mathrm{mEq} / \mathrm{L}$ & 75-g OGTT & \\
\hline K & $4.0 \mathrm{mEq} / \mathrm{L}$ & BS pre & $81 \mathrm{mg} / \mathrm{dL}$ \\
\hline $\mathrm{Cl}$ & $105 \mathrm{mEq} / \mathrm{L}$ & BS $30 \mathrm{~min}$ & $145 \mathrm{mg} / \mathrm{dL}$ \\
\hline FBS & $111 \mathrm{mg} / \mathrm{dL}$ & BS $60 \mathrm{~min}$ & $131 \mathrm{mg} / \mathrm{dL}$ \\
\hline $\mathrm{Hb}_{\mathrm{Alc}}(\mathrm{NGSP})$ & $5.7 \%$ & BS $120 \mathrm{~min}$ & $142 \mathrm{mg} / \mathrm{dL}$ \\
\hline $\mathrm{Fe}$ & $172 \mu \mathrm{g} / \mathrm{mL}$ & Insulin pre & $30.2 \mu \mathrm{IU} / \mathrm{mL}$ \\
\hline Ferritin & $483 \mathrm{ng} / \mathrm{dL}$ & Insulin $30 \mathrm{~min}$ & $257.9 \mu \mathrm{IU} / \mathrm{mL}$ \\
\hline $\mathrm{TC}$ & 268 & Insulin $60 \mathrm{~min}$ & $175.1 \mu \mathrm{IU} / \mathrm{mL}$ \\
\hline LDL-C & 146 & Insulin $120 \mathrm{~min}$ & $395.7 \mu \mathrm{IU} / \mathrm{mL}$ \\
\hline TG & 515 & & \\
\hline CRP & $0.02 \mathrm{mg} / \mathrm{dL}$ & ICG R15 & $2 \%$ \\
\hline
\end{tabular}

ALB: albumin, ALP: alkaline phosphatase, ALT: alanine aminotransferase, AMA: anti-mitochondrial antibody, ANA: antinuclear antigen, AST: aspartate aminotransferase, BS: blood sugar, BUN: blood urea nitrogen, $\mathrm{ChE}$ : cholinesterase, $\mathrm{Cl}$ : chloride, $\mathrm{Cr}$ : creatinine, CRP: C-reactive protein, D-BIL: direct bilirubin, FBS: fasting blood sugar, Fe: iron, Hb: hemoglobin, HBs antigen: hepatitis B surface antigen, HCV: hepatitis C virus, Ht: hematocrit, ICG R15: indocyanine green retention rate at 15 minutes., IgG: immunoglobulin G, IgM: immunoglobulin M, K: potassium, LDH: lactate dehydrogenase, LDL-C: low-density lipoprotein cholesterol, Na: sodium, NGSP: National Glycohemoglobin Standardization Program, OGTT: oral glucose tolerance test, PLT: platelet, PT-INR: international normalized ratio of prothrombin time, PT: prothrombin time, RBC: red blood cells, T-BIL: total bilirubin, TC: total cholesterol, TG: triglycerides, TP: total protein, WBC: white blood cells, $\gamma$-GTP: gamma-glutamyl transferase

tests were as follows: albumin $4.6 \mathrm{~g} / \mathrm{dL}$, total bilirubin 0.8 $\mathrm{mg} / \mathrm{dL}$, direct bilirubin $0.2 \mathrm{mg} / \mathrm{dL}$, AST $86 \mathrm{U} / \mathrm{L}$, ALT 219 U/L, alkaline phosphatase $399 \mathrm{U} / \mathrm{L}, \gamma$-GTP $290 \mathrm{U} / \mathrm{L}$, and prothrombin time $>100 \%$ (Table 2 ). The patient was negative for hepatitis viruses and autoantibodies. He showed dyslipidemia (total cholesterol $268 \mathrm{mg} / \mathrm{dL}$ and triglyceride $515 \mathrm{mg} / \mathrm{dL}$ ). A fasting glucose level of $111 \mathrm{mg} / \mathrm{dL}$ and a he$\operatorname{moglobin}_{\mathrm{Alc}}$ of $5.7 \%$. He also showed insulin resistance, as indicated by a homeostasis model assessment as an index of insulin resistance (HOMA IR) score of 6.07. His indocyanine green clearance was $2 \%$ at 15 minutes. The serum level of leptin was extremely high, at $197 \mathrm{mg} / \mathrm{mL}$ (normal range for males, $0.79-10.31 \mathrm{ng} / \mathrm{mL}$ ). The ultrasound and CT findings showed fibrosis of the liver, but there was no evidence of fatty liver (Fig. 2a, b). The visceral fat area estimated by CT was $166.55 \mathrm{~cm}^{2}$, and the patient showed visceral obesity (Fig. 2c). The liver-to-spleen attenuation ratio was 1.18 . An analysis of his body composition by bioelectrical impedance showed a skeletal muscle mass of $22.6 \mathrm{~kg}$ and a body fat mass of $42.9 \mathrm{~kg}(50.8 \%$, Table 3). Liver biopsy revealed mild microvesicular steatosis with severe hydropic changes of hepatocytes (Fig. 3). Inflammation and fibrosis were both mild. Based on the above, disturbance of beta-oxidation in mitochondria was suspected. The results of 
a fatty acid fractionation analysis indicated an increased serum level of oleic acid.

Treatment with ursodeoxycholic acid, an injectable preparation of glycyrrhizin (an extract of the saponin component of the roots of the licorice Glycyrrhiza inflata comprised of dried roots and stolons), and Stronger Neo-Minophagen ${ }^{\circledR} \mathrm{C}$ $\left(\mathrm{SNMC}^{\circledR}\right)$ were started. The patient's aminotransferase levels were still high (AST, $172 \mathrm{U} / \mathrm{L}$; ALT, $425 \mathrm{U} / \mathrm{L}$; and $\gamma$-GTP, $275 \mathrm{U} / \mathrm{L})$. The $\mathrm{SNMC}^{\circledR}$ treatment was tapered after discharge, resulting in increased aminotransferase levels (AST, $490 \mathrm{U} / \mathrm{L}$; ALT, $996 \mathrm{U} / \mathrm{L}$; and $\gamma$-GTP $266 \mathrm{U} / \mathrm{L})$, and the patient was re-admitted to the hospital. Daily treatment with

a)

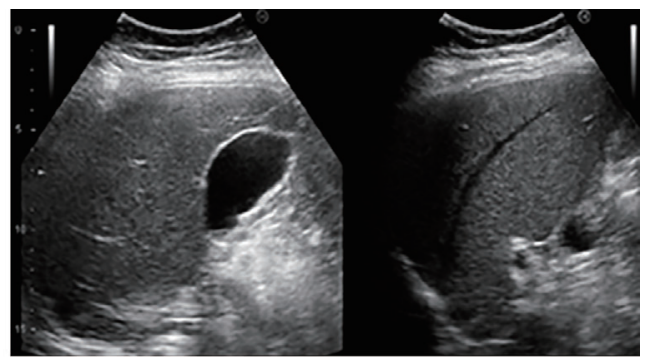

b)

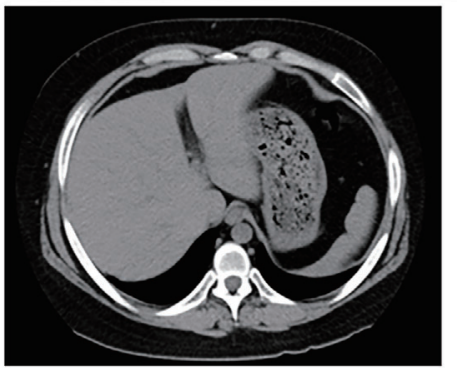

c)

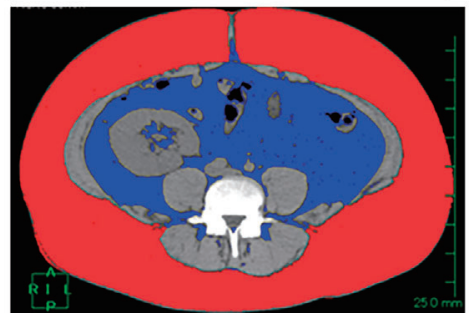

Figure 2. Abdominal ultrasound and CT findings. a) Abdominal ultrasound and b, c) CT scans. Fibrosis of the liver was indicated by abdominal ultrasound and CT, but there was no evidence of fat accumulation (a, b). The visceral fat area estimated by CT was $166.55 \mathrm{~cm}^{2}$, suggesting visceral obesity (c). The liver-to-spleen attenuation ratio was 1.18. CT: computed tomography
SNMC $^{\circledR}$ was continued, and after 1 month his aminotransferase levels had decreased (AST, 193 U/L; ALT, 379 U/L; and $\gamma$-GTP $193 \mathrm{U} / \mathrm{L}$ ). Two months later, his aminotransferase levels had further decreased (AST, $34 \mathrm{U} / \mathrm{L}$; ALT, 60 $\mathrm{U} / \mathrm{L}$; and $\gamma$-GTP, $131 \mathrm{U} / \mathrm{L}$ ), but his body weight remained steady. A genetic analysis was performed at the Department of Pediatrics, Kobe University Graduate School of Medicine, and the skipping of exons 14 and 17 in the sodium channel and clathrin linker 1 (SCLT1) gene was identified (12).

\section{Discussion}

We treated a case of BBS complicated with hepatic fibrosis and microvesicular steatohepatitis caused by impaired glucose tolerance, hyperlipidemia, and hyperleptinemia. Drug administration caused more severe liver injury and the transaminase increase was prolonged. Microvesicular steatohepatitis suggested disturbed beta-oxidation in mitochondria, a rare hepatic manifestation of BBS. SCLT1 skipping may be implicated in this instance of BBS.

BBS is an autosomal recessive ciliopathy. Genetic analyses have identified 21 causative mutations $(6,13)$ that are present in $\sim 80 \%$ of cases of BBS. In our case, the skipping of exons 14 and 17 in SCLTl was observed, as reported previously (12). A proteomics analysis demonstrated that SCLT1 forms the distal appendages of the centrioles and is involved in ciliogenesis (14). SCLT1 is associated with the functioning of cilia; its deletion was reported to cause ciliopathy in mice, and it was therefore considered related to cystic kidney disease (15). Katagiri et al. reported that skipping of exons 14 and 17 resulted in obesity and a renal disturbance in a Japanese population (16). In our case, renal failure, retinitis pigmentosa, obesity, mental retardation, and hypogonadism led to a diagnosis of BBS. Therefore, SCLT1 skipping may be involved in BBS. Although, SCLT1 skipping may be associated with ciliopathy and cystic fibrosis of the kidney, the precise mechanism underlying the development of steatohepatitis has not yet been elucidated.

BBS is a ciliopathy $(6,7)$. The disruption of cilia formation involved in intraflagellar transport causes multiple phenotypes of BBS (17). In Caenorhabditis elegans, only sensory neurons are ciliated, and ciliary defects result in excessive secretion of hormones and altered body size (obesity), feeding, and fat accumulation $(18,19)$. Obesity results from

Table 3. The Patient's Body Composition Based on a Bioelectrical Impedance Analysis.

\begin{tabular}{lclr}
\hline \multicolumn{2}{c}{ Muscle-fat analysis } & \multicolumn{2}{c}{ Body composition analysis } \\
\hline Body weight & $84.5 \mathrm{~kg}$ & Intracellular water & $18.8 \mathrm{~L}$ \\
Height & $156.5 \mathrm{~cm}$ & Extracellular water & $11.8 \mathrm{~L}$ \\
Body mass index & $34.5 \mathrm{~kg} / \mathrm{m}^{2}$ & Protein mass & $8.1 \mathrm{~kg}$ \\
Skeletal muscle mass & $22.6 \mathrm{~kg}$ & Mineral mass & $2.79 \mathrm{~kg}$ \\
& & Body fat mass & $42.9 \mathrm{~kg}$ \\
& & Percent body fat & $50.8 \%$ \\
& & Waist/hip ratio & 1.03 \\
\hline
\end{tabular}




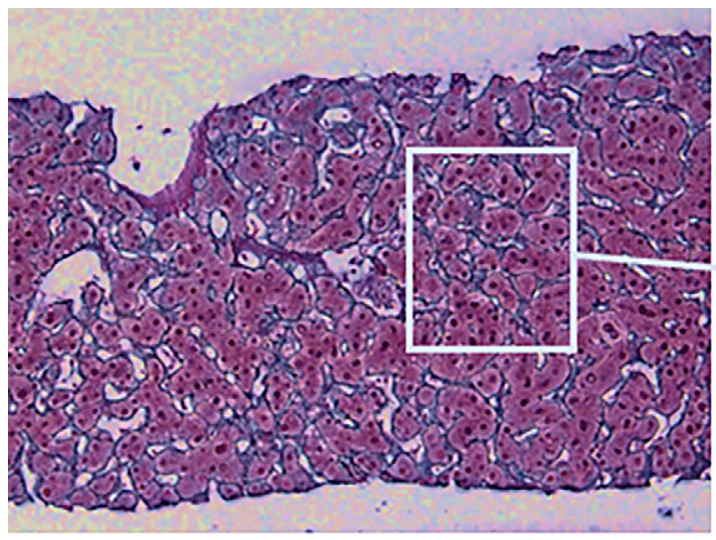

Silver impregnation stain

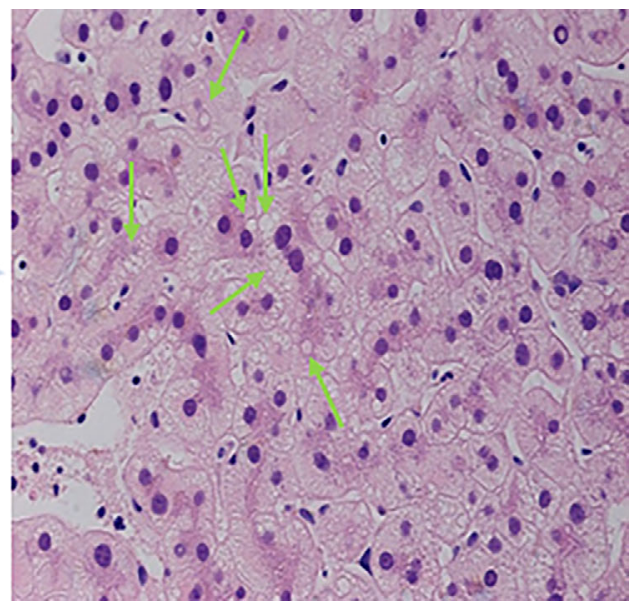

Figure 3. Pathological liver findings. Liver biopsy revealed mild microvesicular steatosis (arrow), with severe hydropic changes in the hepatocytes based on Hematoxylin and Eosin staining. Inflammation was mild. Fibrosis was mild on silver impregnation staining. an imbalance between ingested and expended calories; BBS mice are hyperphagic with a $20-30 \%$ increase in daily food intake $(20,21)$. Moreover, patients with BBS undertake less physical activity, leading to obesity and greater abdominal visceral fat compared to BMI-matched control subjects (22). In the current case, the patient's daily intake of food was controlled by his parents, but his physical activity was low because he was almost blind due to retinitis pigmentosa.

A hepatic complication of BBS, hepatic fibrosis, was diagnosed at 1 year of age. The patient also showed microvesicular steatosis in the liver on liver biopsy. However, there was no evidence of fat deposition in the liver by ultrasound or CT, which ruled out fatty liver. Steatohepatitis occurs in only $18.5 \%$ of BBS cases $(3,23)$. In addition to nonalcoholic steatohepatitis (NASH), hypertension and hypothyroidism can develop in patients with BBS (24). Microvesicular steatosis is observed in $10 \%$ of adults and $19 \%$ of children with non-alcoholic fatty liver disease (NAFLD) (25); it is more common in patients with Reye syndrome or other forms of mitochondrial injury (26). In our case, oleic acid elevation and microvesicular steatosis indicated impaired fatty acid metabolism and caused fat accumulation in hepatocytes.

Insulin resistance and a low skeletal muscle mass may be associated with the initiation of steatosis (27-29). Grace et al. reported that patients with BBS and other obese individuals have similar absolute resting metabolic rates (RMR) (30). Another potential cause of the energy imbalance in this syndrome is the hypothalamic action of leptin (31). Leptin in the central nervous system promotes weight loss by reducing food intake and increasing energy expenditure $(32,33)$. BBS proteins are important mediators of leptin receptor trafficking, and loss of the encoding genes results in leptin resistance (31). Patients with BBS exhibit hyperleptinemia $(21,22)$. In mice with $\mathrm{BBS}$, eliminating obesity and hyperleptinemia by calorie restriction does not restore leptin sensitivity, indicating that leptin resistance is intrinsic rather than secondary to hyperleptinemia and obesity $(34,35)$. In our case, the serum leptin level was extremely high compared to normal subjects. A 1,000 kcal/day diet did not reduce the liver enzyme levels. However, bariatric surgery is reportedly effective against morbid obesity and NAFLD in BBS (36). In addition, in our case, the liver enzyme levels were markedly elevated after drug administration and remained elevated for a prolonged period. The administration of $\mathrm{SNMC}^{\circledR}$ decreased the aminotransferase levels, however, this does not represent a radical treatment for BBS patients. We speculated that the patient's renal function was impaired due to the prior kidney transplantation, which increased the drug concentration and induced liver damage. Although it was unclear whether the microvesicular steatosis was drug-induced or caused by leptin resistance, leptin resistance may well have been the main cause as ezetimibe is not commonly associated with drug-induced steatohepatitis. Although it has been reported that BBS is related to obesity because of hyperleptinemia (caused by a defect in leptin signaling), dysregulation of feeding, and reduced physical activity, not all patients showed steatohepatitis. In this case report, a phenotype similar to other types of BBS, but with a different genetic background, was observed (1-3). Further studies are needed to elucidate the mechanism and determine the management of steatohepatitis in patients with BBS.

In this case, we found no evidence of steatohepatitis until obtaining the liver biopsy results. Microvesicular steatohepatitis is difficult to diagnose by radiological examinations. The inclusion of liver biopsy in clinical workup may increase the rate of identification of cases of steatohepatitis. Clinicians should be aware of the possibility of liver disease during the follow-up and treatment of patients with BBS.

In conclusion, we experienced a case of BBS complicated by hepatic fibrosis and microvesicular steatohepatitis. Insulin resistance, reduction of muscle mass, impairment of fatty acid metabolism, and high leptinemia may cause steatohepa- 
titis.

The authors state that they have no Conflict of Interest (COI).

\section{Acknowledgement}

We would like to thank Prof. Yoji Nagashima of the Department of Surgical Pathology of Tokyo Women's Medical University for providing valuable advice regarding the pathological diagnoses.

\section{References}

1. Bardet G. Sur un syndrome d'obésité congénitale avec polydactylie et réunite pigmentaire (contribution á l'etude des formes cliniques de l'obésite hypophysaire). Thése de Paris 170: 107, 1920 (in French).

2. Green JS, Parfrey PS, Harnett JD, et al. The cardinal manifestations of Bardet-Biedl syndrome, a form of Laurence-Moon-Biedl syndrome. N Engl J Med 321: 1002-1009, 1989.

3. Beales PL, Elcioglu N, Woolf AS, Parker D, Flinter FA. New criteria for improved diagnosis of Bardet-Biedl syndrome: results of a population survey. J Med Genet 36: 437-446, 1999.

4. Pagon RA, Haas JE, Bunt AH, Rodaway KA. Hepatic involvement in the Bardet-Biedl syndrome. Am J Med Genet 13: 373-381, 1982.

5. Nakamura F, Sasaki H, Kajihara H, Yamanoue M. LaurenceMoon-Biedl syndrome accompanied by congenital hepatic fibrosis. J Gastroenterol Hepatol 5: 206-210, 1990.

6. Forsythe E, Kenny J, Bacchelli C, Beales PL. Managing BardetBiedl syndrome-now and in the future. Front Pediatr 6: 23, 2018.

7. Tobin JL, Beales PL. Bardet-Biedl syndrome: beyond the cilium. Pediatr Nephrol 22: 926-936, 2007.

8. Klein D, Ammann F. The syndrome of Laurence-Moon-BardetBiedl and allied diseases in Switzerland. Clinical, genetic and epidemiological studies. J Neurol Sci 9: 479-513, 1969.

9. Beales PL, Warner AM, Hitman GA, Thakker R, Flinter FA. Bardet-Biedl syndrome: a molecular and phenotypic study of 18 families. J Med Genet 34: 92-98, 1997.

10. Hirano M, Satake W, Ihara $\mathrm{K}$, et al. The first nationwide survey and genetic analyses of Bardet-Biedl syndrome in Japan. PLoS One 10: e0136317, 2015.

11. Forsythe E, Beales PL. Bardet-Biedl syndrome. Eur J Hum Genet 21: 8-13, 2013.

12. Morisada N, Hamada R, Miura K, et al. Bardet-Biedl syndrome in two unrelated patients with identical compound heterozygous SCLT1 mutations. CEN Case Rep 9: 260-265, 2020.

13. Maria M, Lamers IJ, Schmidts $M$, et al. Genetic and clinical characterization of Pakistani families with Bardet-Biedl syndrome extends the genetic and phenotypic spectrum. Sci Rep 6: 34764 , 2016.

14. Tanos BE, Yang HJ, Soni R, et al. Centriole distal appendages promote membrane docking, leading to cilia initiation. Genes Dev 27: 163-168, 2013.

15. Li J, Lu D, Liu H, et al. Sclt1 deficiency causes cystic kidney by activating ERK and STAT3 signaling. Hum Mol Genet 26: 29492960, 2017.

16. Katagiri S, Hayashi T, Yoshitake K, et al. Compound heterozygous splice site variants in the SCLT1 gene highlight an additional candidate locus for Senior-Løken syndrome. Sci Rep 8: 16733, 2018.

17. Oh EC, Vasanth S, Katsanis N. Metabolic regulation and energy homeostasis through the primary Cilium. Cell Metab 21: 21-31, 2015.

18. Mak HY, Nelson LS, Basson M, Johnson CD, Ruvkun G. Poly- genic control of Caenorhabditis elegans fat storage. Nat Genet 38: 363-368, 2006.

19. Lee BH, Liu J, Wong D, Srinivasan S, Ashrafi K. Hyperactive neuroendocrine secretion causes size, feeding, and metabolic defects of C. elegans Bardet-Biedl syndrome mutants. PLoS Biol 9: e1001219, 2011.

20. Eichers ER, Abd-El-Barr MM, Paylor R, et al. Phenotypic characterization of Bbs4 null mice reveals age-dependent penetrance and variable expressivity. Hum Genet 120: 211-226, 2006.

21. Rahmouni K, Fath MA, Seo S, et al. Leptin resistance contributes to obesity and hypertension in mouse models of Bardet-Biedl syndrome. J Clin Invest 118: 1458-1467, 2008.

22. Feuillan PP, Ng D, Han JC, et al. Patients with Bardet-Biedl syndrome have hyperleptinemia suggestive of leptin resistance. J Clin Endocrinol Metab 96: E528-E535, 2011.

23. Wanless IR, Lentz JS. Fatty liver hepatitis (steatohepatitis) and obesity: an autopsy study with analysis of risk factors. Hepatology 12: 1106-1110, 1990.

24. Singh Y, Singh M, Saxena SR, Prakash S, Joshi A. Bardet-Biedl syndrome with nonalcoholic steatohepatitis, hypertension, and hypothyroidism. Chrismed Journal of Health and Research 3: 128130, 2016.

25. Tandra S, Yeh MM, Brunt EM, et al. Presence and significance of microvesicular steatosis in nonalcoholic fatty liver disease. J Hepatol 55: 654-659, 2011.

26. Fromenty B, Pessayre D. Impaired mitochondrial function in microvesicular steatosis. Effects of drugs, ethanol, hormones and cytokines. J Hepatol 26 (Suppl 2): 43-53, 1997.

27. Chitturi S, Farrell G, Frost L, et al. Serum leptin in NASH correlates with hepatic steatosis but not fibrosis: a manifestation of lipotoxicity? Hepatology 36: 403-409, 2002.

28. Tilg H, Moschen AR. Evolution of inflammation in nonalcoholic fatty liver disease: the multiple parallel hits hypothesis. Hepatology 52: 1836-1846, 2010.

29. Cai C, Song X, Chen Y, Chen X, Yu C. Relationship between relative skeletal muscle mass and nonalcoholic fatty liver disease: a systematic review and meta-analysis. Hepatol Int 14: 115-126, 2020.

30. Grace C, Beales P, Summerbell C, et al. Energy metabolism in Bardet-Biedl syndrome. Int J Obes Relat Metab Disord 27: 13191324, 2003.

31. Guo DF, Rahmouni K. Molecular basis of the obesity associated with Bardet-Biedl syndrome. Trends Endocrinol Metab 22: 286293, 2011.

32. Stephens TW, Basinski M, Bristow PK, et al. The role of neuropeptide $\mathrm{Y}$ in the antiobesity action of the obese gene product. Nature 377: 530-532, 1995.

33. Zigman JM, Elmquist JK. Minireview: From anorexia to obesitythe yin and yang of body weight control. Endocrinology 144: 3749-3756, 2003.

34. Seo S, Guo DF, Bugge K, Morgan DA, Rahmouni K, Sheffield VC. Requirement of Bardet-Biedl syndrome proteins for leptin receptor signaling. Hum Mol Genet 18: 1323-1331, 2009.

35. Büscher AK, Cetiner $M$, Büscher R, Wingen AM, Hauffa BP, Hoyer PF. Obesity in patients with Bardet-Biedl syndrome: influence of appetite-regulating hormones. Pediatr Nephrol 27: 20652071, 2012.

36. Boscolo M, Féry F, Cnop M. Beneficial outcomes of sleeve gastrectomy in a morbidly obese patient with Bardet-Biedl syndrome. J Endocr Soc 1: 317-322, 2017.

The Internal Medicine is an Open Access journal distributed under the Creative Commons Attribution-NonCommercial-NoDerivatives 4.0 International License. To view the details of this license, please visit (https://creativecommons.org/licenses/ by-nc-nd/4.0/).

(C) 2020 The Japanese Society of Internal Medicine Intern Med 59: 2719-2724, 2020 